SAD / JSR

Sosyoloji Araştırmaları Dergisi / Journal of Sociological Research

Cilt / Volume 22 Sayı / Number 1 (Nisan / April 2019) : (96-121)
Araştırma Makelesi / Research Article

Geliş Tarihi / Submited: 03.08.2018

Kabul Tarihi / Accepted: 30.11.2018

\title{
CONFORMITY VERSUS INFORMALITY: ON RELATIONSHIP BETWEEN THE SOCIALISTS AND BUREAUCRATIC ELITE IN TURKEY
}

\section{Mete Kaan KAYNAR ${ }^{1}$}

\begin{abstract}
Might the history of socialism in Turkey be read as the history of "ostracism" and "proscription" of the socialists from the political system? On the other hand, might the socialists in Turkey be considered as a (one of the) outsider(s) or political (one of the) enemy/enemies? This article wants to answer these questions and focus on the problem of how Turkish socialists affect the political system, while they are in mainly the outside of the system. The main argument of this article is that the socialists can be considered as an outsider/public enemy of Turkish political system by the bureaucratic elite, but social relations occurred in the non-political institutions of Turkish society have given opportunities to the socialists for affecting the political system. In other words, nonpolitical social institutions and daily social relations occurred in these institutions have been the only space for the socialists to be politically active and to illegally and informally affect the inside (formal institutions) of the political system. This is also one of the main reason for the endemic informality and/or illegality tradition in the Turkish left. The main aim of this study is to explore the relationship, interactions, and dilemmas regarding conformity versus illegality in line with the contradictive evolvement of relations between the socialists and bureaucratic elite in the Turkish political life.
\end{abstract}

Key Words: Turkish Politics, Conformity, Informality, Bureaucratic Elite, Socialists.

${ }^{1}$ Doç. Dr., Hacettepe Üniversitesi, İ̈BF, Siyaset Bilimi ve Kamu Yönetimi Bölümü

SAD / JSR

Cilt / Volume 22 Sayı / Number 1 


\section{UYUMLULUK GAYRIRESMİLİĞE KARȘI: TÜRKİYE'DE SOSYALİSTLER İLE BÜROKRATIK ELITT ARASINDAKİ İLISSTI ÜZERİNE}

\section{$\ddot{O Z Z}$}

Türkiye' de sosyalizmin tarihi sosyalistlerin maruz kaldığı "sürgün” ve "yasaklama" tarihi üzerinden okunabilir mi? Veya, Türkiye'de sosyalistler yabancı(lardan biri) veya siyasal hasım(lardan biri) olarak değerlendirilebilir mi? Bu çalışma, bu sorulara cevap bulmaya çalışmakta ve Türkiye'de sosyalistlerin, sistemin dışında iken, siyasal sistemi nasıl etkileyebildikleri konusu üzerine odaklanmaktadır. $\mathrm{Bu}$ çalışmanın ana sorunsalı, Türkiye'de sosyalistlerin bürokratik elit tarafından Türk siyasal sistemininin sözde yabancısı/toplum düşmanı olarak kabul edilebilirken, Türk toplumunun siyaset-dışı kurumlarındaki sosyal ilişkilerin sosyalistlere siyasal sistemi etkileyebilme olanağını verebildiğidir. Diğer deyişle, siyasetdışı toplumsal kurumlar ve bu kurumlarda yaşanan günlük sosyal ilişkiler, sosyalistlerin siyaseten aktif olabildikleri ve siyasal sistemin içerisini (resmi kurumları) gayriresmi olarak etkileyebildikleri yerler olmalarıdır. Bu da, Türk solundaki yaygın gayriresmilik geleneğinin en önemli sebeplerinden birisidir. $\mathrm{Bu}$ bağlamda, bu çalışmanın ana amacı, Türk siyasi hayatında bürokratik elit ile sosyalistler arasındaki ilişkilerin çelişen gelişimi paralelinde uyumluluğun gayriresmilikle çatışması bağlamında ortaya çıkan ikilemler ile karşılıklı etkileşimleri ortaya koyabilmektir.

Anahtar Kelimeler: Türk Siyaseti, Uyumluluk, Gayriresmilik, Bürokratik Elit, Sosyalistler. 


\section{INTRODUCTION}

First of all, the terms "ostracism" and "proscription" related to socialism need to be clear. By the term "ostracism", it is meant that exclusion or expulsion of some of the groups, parties or ideologies from the political institutions where the formal political decision are made. The term of "proscription" means that group of people, ideologies, or parties are forbidden by authority or declared to be dangerous and harmful -or at least- counterproductive of "our" national unity and "our" interest that is described by a bureaucratic elite. $^{2}$

Schmitt (1976: 46-47) defines the term of the political enemy as having a close relationship with the ostracism and proscription. He puts that

“...as long as the state is a political entity this requirement for internal peace compels it in critical situations to decide also upon the domestic enemy. Every state provides, therefore, some kind of formula for the declaration of an internal enemy. Whether the form is sharper or milder, explicit or implicit, whether ostracism, expulsion, proscription, or outlawry are provided for in special laws or explicit or general descriptions, the aim is the same, namely to declare an enemy."

According to Schmitt (1976: 26), friend-enemy relation is integral of the political and "political actions and motives can be reduced is that between friend and enemy." He also argues, “...political enemy need not be

2 The term "elite" which has been inherited from the Antique Greek is one of the key concepts of political theory. The term is derived from the Latin Word "eligere" which means "pick" or "chose". The term "elite" is based on that notion there is a ruling minority, which is a group of people controlling and apportioning the power sources, in all societies. Higley and Pakulski (2012: 1-2) also describe the term as follows: "[Elites]...consist of persons who are able, by virtue of strategic positions in powerful organizations and movements, to affect political outcomes, usually at the level of national states, regularly and substantially." Elite theories are the theories that have relied upon explaining the elite behaviour, interaction, transformation and the connection between those instances. As Lopez (2013:2) also underlined that, "The core of classical elitism is the notion of elite inevitability." Classical elite theoreticians, especially Pareto (in his concept of the "law of elite circulation"), Mosca (in his concept of the "political class") and Michels (in his concept of the "iron law of oligarchy" "...used the inevitability of elite rule as a premise to counter argued with political liberalism and Marxism." (Lopez, 2013:2). In relation with the elite theories and the role of elites in the democratic political systems, see, (Bottomore, 1964), (Dizegara, 1991:340-372) and (Khan, 2012:361-377). 
morally evil or aesthetically ugly; he need not appear as an economic competitor and it may even be advantageous to engage with him in business transactions. But he is... the other, the stranger; and it is sufficient for his nature that he is... something different and alien." (Schmitt, 1976: 27) According to Mouffe (2000: 43), "by stressing, that the identity of a democratic political community hinges on the possibility of drawing a frontier between 'us' and 'them'.”

As a way of declaration of the political enemy in a specific political system, the terms of exclusion, proscription, and ostracism that Schmitt puts are argued with the term of a constitutive outsider by Derrida. ${ }^{3}$ According to him, an outsider cannot be simply reduced to "physically outside" and stressed that the insider describes via the outsider. In other words, outside constructs inside and vice versa.

With referring to Derrida, Schmitt, and Mouffe, it can be said that "to be outside"-or "to be enemy"- does not mean "driven out" "neglected", "forbidden" or simply "abolished", or Schmitt's terms, does not mean "morally evil" or "aesthetically ugly". On the contrary, the political enemy has important roles and functions in the inside of the political system as an outsider, and it helps to describe the "inside of the political system". Although the term of outside cannot be simply reduced to "a specific territory", or "out of somewhere", outside of political system can be considered as outside of the formal political institutions such as political parties, associations, parliament, and laws adjusting the political life. In other words, outsider can be described as an ethnic, ideological and/or religious minority -who are ostracized proscribed by the bureaucratic elite ${ }^{4}$ who have been dominant and able to define the "national interest", who are

${ }^{3}$ For the terms "outsider" and "insider" of Derrida, see, (Derrida 1974, Chapter 2), (Bennington, 1997) and (Morrison 1998/99: 40-65).

4 Özcan (2015:155) describes the bureaucratic elite as follows " .... high level group of state employees which have the authority to use the will derived from the power of the state, having the knowledge and technical expertise and the will to control the community/state/economy with an 'elitist' approach by obstructing democratic processes and who have an influential role in the political decision making process." The Turkish Republic has inherited a strong bureaucratic state from the Ottoman Empire. In this state tradition, bureaucracy is perceived as a power group that always endeavours to maintain its power in the political and social system. For this reason, as Özcan (2015:156) underlines, “...bureaucracy in the Turkish community is not the kind which 
blocked to achieve formal political institutions- whereas everybody in the political system is declared to have equal rights to join the political system by the Turkish Constitution. Here is also space for Turkish socialists to live politically.

This relationship of the political system with the left-wing groups also bound up with the role of the elite in the modernization process of Turkey. It can be said that the bureaucratic elite has found such a "power" in their historical role of the positivist modernization process of Turkey. In other words, state -and its elitein Turkey has been able to control social-cultural change and the modernizing elite, especially army, ${ }^{5}$ have been able to control the state and political institutions/life. Therefore, non-political societal institutions have been only space for the socialists. Whenever the socialists in Turkey have shifted their political activity from the non-political societal institutions to formal political institutions, or, in other words, attempted to join institutional politics (with political party, association or a formal journal etc.), each of attempts has been either stigmatised as a "dangerous ideology" or "organisations smuggled into our society by national enemies", and then, all these attempts have been blocked and declared to be outlawry. Actually, it should be stressed that the collapse of the Soviet Union made this discourse, used by the bureaucratic elite against the socialist thought and the socialists themselves, absurd. However, socialism -as a (one of the) outsider(s),

implements the decisions taken by political power but which partakes in their making. Pustu (2007:198) highlights that bureaucratic elitism "...stemmed from bureaucratic administration regime in the Ottoman-Turkish states reinforced the structure of OttomanTurkish society and state systemic elitism, thus had a significant role in the relationship between state and society. Bureaucratic elites developed as an exclusive class in the Ottomans' kul system and historically played a modernization agent role in the structures of state and society. In this context, they had considerable effects after the Tanzimat period and considered society as collectivities that needed governing and modernizing." Burak (2011:62) also argues that the Turkish state "...from the very beginning consolidated its power by representing itself as the carrier of highest ethical values and appointed itself to the role of civilizing the 'irrational' masses. The modernization project carried out in a top-down fashion deeply affected the evolution of civil society in Turkey. That statist, top-down fashion paved the way for Turkish civil society to become very fragile from the very beginning." In relation with the state tradition in Ottoman-Turkish political regime and the roles, the functions and the qualifications of bureaucratic elites on the modernisation period, see, (Keyder, 2014), (Heper, 1976), (Heper, 1985), (Demirkol, 2013:70-85), (Sayın, 2006).

${ }^{5}$ Hale and William (1994) and Jenkins (2001) also stress that the Turkish military has been predominance in public and political life of Turkey. According to the authors, although the Turkish Republic founded upon the mystique of civilian supremacy, this predominance inherited from the Ottoman state-tradition, which made the Turkish Army modernising force. 
(or one of the) enemy/enemies is still one of the main apparatus of describing the "we". Thus, it is still strongly possible to see one who is officially labelled and sentenced as a "communist". On the other hand, the socialists have reacted to these treatments with organizing into informal/amorphous associations/parties/fronts and informal journals/newspapers, which are handed out within the same group, and with the informal parties trying to subvert the current regime.

In sum, what the philosophers describe as an outsider, or political enemy seem to be proper conceptual implements to explain the political position and functions of the socialists in the Turkish political system. It also seems to be convenient to explain why all of the socialist parties have legally abolished, and why they have been stigmatized as a traitor or described as a weirdo, strange or odd, although socialist parties, associations etc. have always acted in the political life of Turkey in some ways. There are a few main reasons to be mentioned: firstly, it is strongly underscored that the intentions of the elite in Turkey go beyond the aim of neglecting or driving out the socialists. On the contrary, it is quite true that their intention and aim have been either keep socialism "there" (out of the formal political institutions) or in the space that the state could manipulate and control. After giving some examples of how the bureaucratic elite try to keep the socialists into the state-controlled (or corporate) political space, the functions of socialism as an outsider in the Turkish political system is detailed. How the socialists had been proscribed, and ostracized form institutional politics, in other words how elite keep them "there/outside", and declared them as an enemy will be third.

\section{BUREAUCRATIC ELITE EFFORTS TO KEEP SOCIALISTS IN STATE- CONTROLLED POLITICAL SPACE}

Official Communist Party of Turkey can be given as a very good example of how the bureaucratic elite try to patronize the socialist movements (or any other ideologies criticizing the bureaucratic elite). Party was founded by the group of politicians and journalists who were ordered by Ataturk's himself in 18th October 
1920. Ataturk wanted the party to serve two important functions: To keep the relation warm with the USSR and block the political activities of the formal/informal Communist Party of Turkey. To achieve these aims, the founders of state-controlled (official) communist party adopted the same name as the real one. Their official newspaper, New World, also had the same name as the newspaper published by real communist party continuing its political activity within the non-political institutions of society. Moreover, the official Communist Party applied to Second International to be a member, but this application was rejected.

As Harris (1967: 7-8) puts, Ataturk's intention was to collect the all of the socialists into the same party dominated and controlled by state and merge the socialism, which was alleged to be counterproductive with the idea of modernization, with this main preference -Western style of modernization- of the Turkish state. Seeing that he failed at gathering the entire socialists in the state-controlled communist party, they had prohibited to all the socialist movements in Turkey, ${ }^{6}$ or in other words, force them to go out of the formal political system.

The further example also possible: Thinking that the workers in Turkey might want to organize into trade union and that this trade union might be socialist like any other counterparts in the world, bureaucratic elite encouraged the worker's leader to found a trade union (Türk-Işs) in 1952. However, they wanted the founders of the trade union not to bias towards any ideology (that is socialism). The plan of the elite was the same as the plan of Ataturk: Keep the workers, who were thought to be socialist, within the statecontrolled space. This plan had worked until the late 1960s. But later, this trade union divided into two in 1967, and, the first socialist trade union in Turkey -Confrontation of Revolutionary Workers Union (DİSK) - was founded.

${ }^{6}$ In relation with the state-controlled Communist Party of Turkey, see, (Harris 1967), (Erdal, 1983). 
Another example can be given from military rule in the 1980s. After the military rule made a decision that democratic(!) election was held in 1983, National Security Council, which was consist of the military who subverted the political system, wanted (or ordered) to be founded a social democrat party- Populist Partyalthough they were strongly against any colour of left. Each of the founders and members of these parties (both leftist and wet-rightist parties) were allowed after thoroughly scrutinizing by the National Security Council. As it is clearly seen, their aim was not so different from the aim of Ataturk ordering his friends to found a communist party or the aim of the bureaucratic elite of the 1960s wanting founders of trade union not to be biased towards socialism.

\section{REASONS OF BUREAUCRATIC ELITE'S EFFORTS TO KEEP THE SOCIALISTS OUT OF THE FORMAL POLITICAL SYSTEM}

As it was underlined above, according to Derrida, "to be outside" and "to be neglected" are different in meaning from each other. In addition, an outsider cannot be accepted as a dysfunctional. What Derrida says easily go for the position and functions of the socialists in Turkey. Thus, it is quite true to say that the Turkish socialists have not been dysfunctional and that the socialists, as an outsider, had played an important role as well, and had an important function in the political system since the Republic was founded. Two main functions can be mentioned.

First, the terms of "socialism" and "socialists" have helped the elite to describe the "we" and "our national unity and interests". As an example of the politically strange, weirdo and dangerous, the socialists have been the exact sample of what "we (ordinary Turkish citizen) are not" and "what we should not be". Rumours about socialism have also been a very effective way of describing the socialists as a strange, weird and/or dangerous, and way of describing "our" political characteristics as well. These rumours have helped them to describe socialism as a "fear". According to these rumours, as a notorious enemy, socialism is against Islam, free trade and family structure of Turkish society: If the socialism, which is an ideology 
introduced by the Jewish so as to expunge Islam from the world, had been come to the power, the new (socialist Turkish) state would have expropriated everything that people possess, all the Mosques would have been destroyed, all moral and traditional values ordinary people possess would have been corrupted, everyone would have been obliged to share his women with others, family would have been abolished, everyone would have worn the same clothing given by the state etc.

Obviously, these discourses/rumours have helped civil and military elite -and the right-wing politicians as well- to present themselves as a group of people who protect the all-Turkish citizens from the imminent enemy, the socialists. According to them, socialism is abhorrent to the characters of Turkish people. None of the Turks "can" be a socialist and vice versa: Most of the socialists, especially their leaders, have been sent and financed by our national enemies, who want to weaken our national unity; rest of the socialists have been mere youths deceived by these leaders sent by the enemies; if the youths who biased towards socialism had been illuminated, they would have understood what the dangers of socialism were and opted out to socialism.

As it was underlined above, these discourses/rumours have effectively used by not only civil and military bureaucracies but also the right-wing and nationalist politicians. Several books and pamphlets, which are financed by the prime ministry, the military or right-wing parties, associations and paramilitary organizations, have published in order to open out the "real face of communism" and "to protect youth from this social and political disease". These books have also helped to describe how we should protect ourselves from the disease of communism and became an ordinary citizen. Karpat (1973: 67) also underlines this fear that has been spread by the politicians and bureaucrats; "The political future of Turkey depends on largely upon the power alignment of various social groups. The present fear of socialism may induce some officers, professional groups, and old-time 'etatists' to form a rightist social coalition.” 
The second function of the socialism in the Turkish Political system, as an outsider, is that this fear created by bureaucratic elite helps them to justify their policies and inefficient democratic political system dominated and steered by himself or herself. First of all, the dangers of socialism -actually, it should be stressed that today, fear of fundamentalist terror and/or of Islamic state works better than the fear of socialism, but it is also underlined that the socialists are still member of outsider/public enemy- helps the elite to justify their policies. According to them, these policies, which will "eventually" reach us the modernization aim, turn into the policies, which bureaucratic elite must make in order to protect "our" nation from the domestic and foreign enemies.

This figure of danger, which has been effectively used by the right-wing politicians and elite since The Republic was founded, makes easier to underline the modernizing role of bureaucratic elite steering this process. For all former-USSR and Republic of Turkey were founded more or less the same period of time, and USSR has ideologically enormously affected on independent wars going on in the third world, founders of Turkish Republic -and their successors have- preferred to follow in the Western countries' footsteps. These historical facts have also helped the successors of Turkey to describe the socialist movements in Turkey as an opposite way of capitalist/positivist modernization at which they aimed, and still help.

Once policies are described as policies, which are necessary to achieve the national $\mathrm{aim}^{7}$-modernizationand to cope with national dangers, cadres of modernization find a proper way to neglect and stifle any domestic demands of democratization and political freedom and to explain the current inefficiency of Turkish democracy, which is patronized by themselves. From the positivist point of view of these cadres, the reasons are so simple: Policies and decisions made by them are "necessary" to be "a modern country" and critics are counterproductive because there is no any other alternative way or policy to be followed in

\footnotetext{
${ }^{7}$ In relation with the positivists, the etatist way of modernization in Turkey, see, (Frey, 1965), (Heper 1994: 231-242).
} 
order to be a modern country. So, dissents should (or have to) be kept outside of the political institutions in which political decisions are made.

It should be underlined that this verdict of the bureaucratic elite summarizing above is closely related with their understanding of positivism and of modernization. From bureaucratic elite's point of view, modernization is a way of science and civility, and its correctness has scientifically proved in Western societies. In other words, modernism has not stemmed from any specific societal structure, but contrary, it only comes from the science and the modern Western countries are just the countries that have been the first to reach this social and political "aim". For this reason, any criticism of Turkish modernization -in other words policies of bureaucratic elite- can come from either unenlightened/uncivil people or the people wanting to stray the elite (as a protector and guardian of modernization process in Turkey): The former should be enlightened and civilised, the latter should be kept in outside.

From this point of view, understanding of the politics of the elite can be described with the term "legitimization from the top", or another word, "self-legitimization". ${ }^{8}$ Despite the fact that both Palma (1991: 55-58) and Marcus (1982: 82-93) use these terms for describing the legitimization of communist states, ironically, these terms also seem to be suitable for the explanation of political mentality of civil and military elite in Turkey. Palma stress that when rulers believe that they have a right to rule needs no popular verification, two consequences can be given as follows; (1) Those subjects who fail to recognize the rulers' right to rule are not thereby impugning the rulers; rather, they are impugning themselves (in other words, criticism towards the regime can come from either unenlightened people or the people wanting to stray the decision makers from this process: the former should be enlightened, the latter should keep outside); (2) If a crisis of legitimacy eventually strikes, as it has been started to occur in Turkey in the early-1990s -that is,

\footnotetext{
${ }^{8}$ For these terms, see, Palma (1991: 49-80) and Marcus (1982: 82-93).
} 
if the rulers lose confidence in their right to rule- it becomes very difficult to stop the crisis. Palma also describes the characteristics of the legitimization from the top, which is closely fit the legitimization of elite in Turkey.

Then, Palma (1991: 57) puts these characteristics as follows:

- Legitimization of rule in the light of goals implies legitimization of bureaucracies,

- Bureaucracy claims a monopoly on political discourse. Thus, their truth cannot be falsified by reality, their commands are always correct, and their tasks can never fail by their shortcomings,

- Authentication of the truth does not need the people. On the contrary, the truth enjoins the people to learn and disseminate it, to bear witness to it,

- When legitimization comes from the top, the decisive operative relationship is not that between rulers and people, but that between rulers and cadres.

According to the bureaucratic elite, "full democratic regime in Turkey" is not only the aim of those who criticise political system as an undemocratic or semi-democratic, but also the aim of the political system itself. However, according to the elite, these concepts such as freedom of speech, human rights, operative democratic politic system and civil society can only find their exact descriptions in the modern (Western) societies; all social and political rights will eventually be enjoyed when "we" achieve this aim. Besides, in this political stage of modernization in Turkey, excessive political rights give the person who unenlightened or deceived by the national enemies' chances to make this process deviate or slower than it should be.

"The bureaucratic elite's figures of enemies", "discourse of the modernization aim" and "the understanding of ordinary citizen who can be deceived by those who are financed and supported by enemies" have mixed and merged in the popular discourse of the Turkish political system since the Republic was founded. Moreover, it is quite true to say that, these are proper implements to describe legitimization from the top in 
Turkey. In brief, bureaucratic elite, who believe how to reach the modernization aim by themselves, have been steering political system since the Republic was founded. According to their discourse, socialism is counterproductive, and this ideology, which is manipulated by the neighbours of Turkey, have tried to hinder Turkey from achieving modernization efforts as well. Nevertheless, it is the fact that this point of view accepted by the civil and military elite in Turkey is one of the main political and cultural reasons of the lack of democratic transition and reasons of stifle of intense democratization demands coming from inside of -institutional- political system until the mid-1990s. In other words, while bureaucratic elite has tried to keep the socialists out of the system in order to consolidate the democratic regime in Turkey and to reach the modernization aim, the same bureaucracy also shrinks the democratic political system in order to keep them out. Here is the real dilemma of the Turkish bureaucratic elite and of the Turkish political system as well. This dilemma also helps us to explain and understand why the socialists had been the unique "hostis" until the late-1990s and to why they are still one of the public enemies. Although, today, fundamentalism (and fundamentalist terror) gain importance, socialism still consider as a notorious and foremost enemy/hostis.

\section{TENET, CADRES AND CONFORMITY: REQUIREMENTS OF BEING AN INSIDER}

Briefly, as an outsider, socialism helps the elite to describe the inside of the political system. While the socialists are described as a weird, strange, and danger, civil and military elite try to answer the questions of "who are we?" and "who should not be?" with this description. Secondly, as it is stressed above, positivist modernization perspective of bureaucratic elite also very important. From the elite's point of view, the needs of modernization process have been beyond the ideologies. Moreover, according to them, ideologies might make the Turkish Republic stray from this process: Although inefficiency and imprecision of the current democratic system, there is no another way. So, any of the members of Turkish society cannot and should not argue with what the state (civil and military elite, bureaucracy) says, believes or thinks. In other 
words, with the words of the 1982 Constitution, "no protection shall be afforded to thoughts or opinions contrary to Turkish National interests, the principle of the existence of Turkey as an indivisible entity with its state and territory, Turkish historical and moral values, or the nationalism, principles, reforms and modernism of Ataturk, and that as required by the principle of secularism, there shall be no interference whatsoever of sacred religious feelings in state affairs and politics.

As being stressed in the Constitutions of Turkey, the Turkish state (that is, its bureaucratic elite) and society have undetectable unity; in other words, civil society, politicians, political parties and individuals have to share the same beliefs, thoughts, and/or policies with civil and military elite. In fact, the socialist movements in Turkey have been merely willing to share the same believes or thoughts with the state elite and preferred to organize into the informal organization. Institutional continuity of formal socialist parties also shows us how the socialists are ostracized and proscribed and why the socialists prefer to informally organize into the non-political institutions of the social system. Before opening out institutional continuity of socialist parties in Turkey, it should be strongly stressed that the "to be a formal" does not always mean that "based on the law" or "allowed by law", but also generally means that organization, party, group of people etc. which is confirmed with political bias of the state and its elite. This understanding of the term analysing above is also the answer to why socialist parties/organizations have generally preferred to organize into the informal organization. Briefly, socialist organizations and parties do not share the same beliefs and thoughts with the bureaucratic elite and bureaucratic elite think that as Palma (1991: 57) stressed, “...their truth cannot be falsified by reality, their commands are always correct, and their tasks can never fail by their shortcomings." This is the key point of the problem.

From the era of Turkish Independent War in 1920s to the 1980 military coup, the number of the formal socialist parties (other left-wing parties such as social democrats and greens, and semi-political associations biased toward socialism such as profession-associations, trade-unions, and human rights associations and 
the other non-governmental left-wing organizations exclude from this amount) had been 22, and all of them were abolished. A number of the informal socialist parties was 130, some of which tried to found a formal brunch, in this period. After the 1980 military coup, none of the socialist parties -or organizations- was allowed to be found. Actually, there were few people willing to found a socialist party, after seeing policies of junta: After the military coup, 517 people, most of whom were socialist, were sentenced to death and 26 of them got the death penalty. In the first three years of the military government, 252 people were killed in the jail, 650.000 people, most of whom were a socialist sympathizer, and 2127 journalist were taken into custody and ill-treated as the reports of Human Rights Foundation (1996: 15-51) and Amnesty International (1989: 1-8).

Moreover, it should be underlined that abolishment of the political parties -especially socialist parties- are usual. A few examples as follows: In the early 1990s, the Turkish United Communist Party, Socialist Party and Labour Party of People were founded, which all were abolished after their foundation. Whereas the Socialist Party was re-founded in the name of Workers Party, supporters of Labour Party of Turkey (re)organise into the Party of Democracy. Party of Democracy was also abolished in 1994 and the Party of Democracy of People was founded in the same year. Turkish United Communist Party also shared the same end with the Party of Democracy. In the last elections (March 2004), just five socialist parties of the total were allowed to join the elections. ${ }^{9}$

Besides this analysis, the density of participation of socialist parties in the formal/legal-political system and elections are also important to stress the position of the left as an outsider. Although 33 formal parties have been founded, most of the formal parties were hardly interested in general elections or formal political

9 The full list of Turkish left can also be found in the Family Tree of the Turkish Radical Left. https://www.broadleft.org/tr_left_part_hist_diag.pdf; especially see, Kaynar (1999).

$\mathrm{SAD} / \mathrm{JSR}$

Cilt / Volume 22 Sayı / Number 1 
activities and agenda. General elections are just considered as a time to propaganda and agitation. Most of them have never participated (and those labelled as an illegal/terrorist leftist groups have not had to right to participate) in any general election. Only one exception in this issue was the Turkish Workers Party (TWP). Party was the first to join the General Elections and is the first and unique socialist party that has an MP in the Grand National Assembly: Turkish Worker Party joined General Elections held in both 1965 and 1969 . While the party gathered, 3\% of the total votes in 1965, votes gathered in 1969 was 2,8\%. Just before the General Election in 1969, the Law of Election had been changed. The main aim of this change was to preclude the TWP from entering the Parliament. In other words, the main aim was to ostracize the TWP from the institutional politics, and the plan was worked: Whereas the TWP had 15 MPs and 3\% in 1965, after the General Election in 1969, which the TWP had, 2,8\% of the total votes, Party had no MP. In the end, the party was abolished after the 1971 military coup. 10

\section{REACTIONS OF LEFT: DIFFUSING FORMAL PARTIES WITH THE INFORMAL ORGANISATIONS}

Looking at socialism as an outsider is not only endemic in the bureaucratic elite but also endemic in the socialists. Especially in the period of 1960-1980, when the socialist movements were very strong, discussions on formality-informality were so popular among the socialist group. After the 1965 General Election, which Turkish Worker Party gathered 3\% vote, the idea that socialism could be built within the democratic system gained popularity among the socialists. However, attacks of rightist paramilitary bands, which were supported and financed by the bureaucratic elite, rightist and nationalist parties and USA, on the socialists made socialist groups re-evaluate to the idea of "socialism within the system". After the assassination of Prime Minister of Chile, Allende, next to all of the socialist organizations started to drive

${ }^{10}$ For policy and ideas of TWP, see (Lipovsky, 1992).

SAD / JSR

Cilt / Volume 22 Sayı / Number 1 
the same conclusion: Achieving socialist ideas within the parliamentary system cannot possible not only in Turkey, but -as it is seen in Chile and the other Latin American countries- also all over the world; and an ordinary Turkish socialist started to think that "real" socialist must be outside of the system, socialist trying to join the formal politics is just "conformist."

The popular idea of the 1970s that socialism was impossible within the system and that only way of building socialism was "revolutionary action from outside of the political system" also led the socialists on to organize into the informal organisations. In other words, while the bureaucratic elite has been trying to keep the socialists outside, the socialists' their own agenda and political biases also made informality popular. From this -socialist- point of view, it has been said before, informality -or to be outside of the systembecame necessary to tackle the political circumstances of Turkey. Today, ostracism" and "proscription" of socialism still works, but mainly with the different apparatus: Corporate media. Socialist parties/associations etc. have had a chance to be seen on TV or newspaper, but just concerning their inefficiency and, their "wrong" policies and their relationship with violent.

Unfolding the general functions and aims of formal socialist associations/parties in Turkey also help us to stress to the position of the socialists as an outsider. In relation to left-wing associations, first, it should be stressed that socialist groups in Turkey have not been -and have not found a chance to be- a "formal" in the full sense of the word. Nevertheless, either they have tried affected to formal associations or to be founded a formal branch in order to voice their policy/ideology. Although it is possible to say that this trend is recently changing, many of the informal socialist organizations still prefer to join the political game with dominating formal associations. The result of these preferences have not been good for the socialist movements in Turkey: None of them are neither politically popular among the ordinary people, nor effects on the political agenda of Turkish political system, nor adds new political ideas or projects to socialist thought in Turkey. Moreover, several informal groups of the socialists compete with each other in order to 
gain influence into these "formal" associations. In other words, "formal" associations (organizationswithin-the political system) have been one of the main political spaces of informal organisations.

Two main reasons can be mentioned about the informality tradition of Turkish left. First, as it was underlined above, formality in politics have generally meant (or required) strict conformity with the tenet of the bureaucratic elite. This tenet has not always meant "Kemalism", which have been derived from the policy of era of Ataturk, but always means tenet that bureaucratic elite has justified their discourse and policy with the word of the Kemalism. ${ }^{11}$ In other words, informality is the simple way of evasion of conformity for the socialists. ${ }^{12}$

The second reason for this is close with their reliance on political system: Informal groups simply have tried to protect themselves against to be arrested and/or ill-treatment by doing so. In addition, this bias is still ongoing. Unfortunately, it is not wrong to say that the history of Turkish socialism, which has been full of assassinations, arrests, and exiles, has enough evidence not to rely on what elite have done or said: Assassination of Leader of Ottoman Socialist Party, Hüseyin Hilmi, and founders of Communist Party of Turkey, Mustafa Suphi and his fourteen companions; arrest and exile of the leader of the Turkish Socialist Worker and Peasant Party Şefik Hüsnü Değmer; execution of the Deniz Gezmis, Hüseyin İnan and Yusuf Aslan in 1972; arrest of nearly all of the members of the CPT in the 1922,1925,1927,1929 and 1932; blockage of the Turkish Worker Party with changing the Law of Election and abolition of all of the socialist parties and associations in the period of military intervention can be given as a key example. Those facts listing above can be considered as one of the main social and political-cultural reasons for the tradition of

${ }^{11}$ For the legacy of Ataturk in the Turkish Political Structure, see, (Cooper, 2002: 115-128).

12 This evasion can be seen nearly in all "dissent" movement in Turkey. For example, the Islamist movements also have effectively used this method. Like socialist movement, Islamist organisations have tried to gain influence into the formal associations as well. For the impact of Islamists on the political system, see, (Feroze, 1976), (Geyikdagi, 1984).

$\mathrm{SAD} / \mathrm{JSR}$

Cilt / Volume 22 Sayı / Number 1 
informality in the Turkish left. Patronizing formal associations and political parties are another way of escaping conformity with the tenet. The case of the Communist Party of Turkey can be given as an example of "How informal organizations have used to formal associations and parties for their political purpose?" Founding in 1920, the CPT is the oldest and the one of the informal parties in Turkey, but party preferred (or had to) patronize formal associations instead of directly joining formal political system: For instance, Progressive Youth Association and Progressive Women Association, two of which were formal organizations, patronized by the CPT activists in the 1970s. 


\section{CONCLUSION}

Even though this study is focused on the roles of the socialists as a political enemy in Turkish political life, it must be strongly underline that the socialists (and conceptually socialism) have not been accepted the only enemy of Turkish political structure. Besides, the Kizilbaşs (redheads/Alevis) and the Kurds have also been accepted as other enemies in this structure. The word "komünist" in Turkish is generally accepted as a synonym with leftist for all kind in the liberal and conservative political discourses of bureaucratic elites It should be highlighted that the "komünist" (as a Turkish word which includes all of the leftists) the Kizilbaşs and the Kurds -all of three words start with "K" letters- have been (nick)named as the " $3 \mathrm{~K}$ " in this discourse. (Kaynar, 2007:77-116). Political enemy role of the socialists has not been ended as a whole during the post-Cold War. It can be said that the socialists are still playing a political enemy role in the political system dominated by liberal and conservative bureaucratic elites as can be seen in the Gezi Protests in 2013 as well. Besides, the Kisilbaşs and the Kurds have also been accepted as the other enemies in this structure. It may be more eligible to say that the socialists, the Alevis and the Kurds are not different kinds of enemies in political discourse, on the contrary, they are -unfortunately- generally accepted as different faces of the same (so-called) enemy. ${ }^{13}$

Further examples about the relationship between Turkish socialists and bureaucratic elite possible, but concisely, although differences between formal-informal, outside-inside of the system seem to be confused in the Turkish case. It can be thought that associations and political parties as an organization within the institutional political system have played a key role to join the institutional politics for the informal socialist organizations. This, of course, has made formal associations' nonsense and intermittent organizations and prevented them to be different from the informal socialist movements and to be organizations that really

${ }^{13}$ In relation with the roles of the socialists as enemies of Turkish political system, see, (Yaşl1, 2015: 151-214), (Bora, 2016: 928), (Kerestecioğlu, 2016: 29-43) and (Öztan, 2016: 425-458).

$\mathrm{SAD} / \mathrm{JSR}$

Cilt / Volume 22 Sayı / Number 1 
think and act within the political system. It is also a fact that this tendency also has prevented the socialists from being a politic gravity. However, at the same time, somehow, helped the informal organizations proscribed and ostracised from the institutional political system to join the political system.

As a result, this study mainly concludes that the Turkish left has been mostly left outside of the system. Although the political system has tried to keep them outside of the system and stigmatized them as a weirdo, strange or enemy, socialist groups and parties have always found a way to join the system. Organizing into the non-political institutions of society have been the first and endemic way of solving this dilemma. By this way, the socialists have tried to protect themselves from the assassinations, arrests and exiles. Patronizing the formal association has been another way to join political life. The bureaucratic elite of the Turkish Republic also makes a profit from this relationship. First, the socialists have been used for describing the "ordinary citizen", for limiting the formal opposition and for explaining the inefficiency of Turkish democracy. Naturally, the bureaucratic elite has not been unique guilty of the informality tradition in Turkish left. Those believing that to be a socialist is strictly required to be an enemy of the current regime and those considering socialism as a handbook of their political violence has also shared this responsibility in Turkey. 


\section{ÖZET}

Türkiye' de sosyalizmin tarihi, sosyalistlerin maruz kaldığı dışarıda bırakma ve engellemenin tarihi olarak okunabilir mi? Ya da Türkiye'de sosyalistler, öteki ve/ya siyasal düşman kavramları etrafinda ele alınabilirler mi? Bu çalışma, bu sorulara cevap bulmaya çalışmakta ve Türkiye' de sosyalistlerin, sistemin dışındalarken, siyasal sistemi nasıl hala etkileyebildikleri, siyasal yapıda nasıl hala işlevsel olabildikleri konusu üzerine odaklanmaya çalışmaktadır. Bu çerçevede konformite ve informalite kavramlarının, ötekileştirilen solun, siyasal sistemin içerisinde yer alma girişimlerinin birer taktiği olarak belirdiğini de vurgulamak gerekmektedir.

Çalışma içerisinde ilk önce, dışarıda bırakma (ostracism) ve engelleme (proscription) kavramları ele alınmaya çalış1ır. Dışarıda bırakma, sürgün gibi anlamlara gelen ostracism kavramı, coğrafi anlamda bir gönderme, sürme, sürgün etme gibi anlamlarından çok -bu çalışmada- sosyalist bireylerin, grupların, partilerin ya da bir bütün olarak sosyalist düşüncenin, siyasal kararların verildiği kurumlardan dışlanması, dışarıda bırakılması ile ilgili tüm süreçleri ifade etmek için kullanılmaktadır. Dışarıda bırakma, dışlanma kavramını, sosyalizmin demokrasinin demos'unun sınırları dışına sürgün edilmesi gibi bir metaforla ele almak da mümkündür. Engelleme (proscription) kavramı ise dışlanmayı tamamlayan bir kavramdır. Bir (sosyalist) grubun, ideolojinin veya partinin (siyasal kavram ve kararların üretildiği, yeniden üretildiği ve topluma aktarıldığı bir kavramsal alan anlamında) siyasal merkez tarafindan yasaklanması, tehlikeli ve zararlı olarak markalanmasını ifade eder. Bu kavramların Schmitt'in hostis ve politik düşman ya da Derrida'nın öteki, yabancı (outsider) kavramları ile yakından ilişkili oldukları da belirtilmelidir. Dışarıda bırakma ve engelleme, Mouffe'un da vurguladığı gibi bir siyasal sistemin sınırları çizilirken ihtiyaç duyulan biz ve onlar ayrımlarının da temellerine yerleşirler.

Bu haliyle, geçmişten günümüze Türkiye'de sosyalizmin (ve sosyalist kişiler, gruplar, partilerin.) siyasal sistemin ötekisi, onları, engelleneni, dışarıda bırakılanı olarak tanımlanması yanlış olmayacaktır. 
Türkiye'de sosyalizmin bu kavramlar eşliğinde tanımlanması, onun Türkiye'de tamamen işlevsiz, anlamsız, yok hükmündeki bir düşünce ve pratik olduğu anlamına gelmemektedir. Aksine bir onlar olarak sosyalizm, siyasal sistemin biz’inin tanımlanması açısından oldukça önemli işlevlere sahiptir.

Rejim ve onun -sosyolojik ve siyasal anlamda- elitleri, bir hostis (kamusal düşman) olarak kodladıkları onlar'1 (sosyalistleri) biz'in ya da farklı bir ifadeyle belirtmek gerekirse makbul vatandaşın taşıması gereken niteliklerini belirtmek için kullanırlar. Bu anlamıyla sosyalistler (ve sosyalizm) asında makbul vatandaşın zıddı, ahlaki ve siyasi olarak bir makbul vatandaşın sahip olamaması gereken tüm özelliklerin müşahhas hali olarak da zuhur ederler.

$\mathrm{Bu}$ ötekileştirme ve politik düşmanlaştırmaya karşı sosyalist sol, kendisine biçilen bu rolü kabullenen hatta içselleştiren bazı sol grupların haricinde, rejimle konformite ve informalite yoluyla irtibat kurmaya çalışa gelmiştir. Sosyalist solda konformite, rejimin kimi temel kavramlarını, o kavramlara rejimde yüklendiğinden farklı ve muğlak anlamlar vererek sistemle uyum sağlamak (comformity) şeklinde tezahür etmektedir. Infromalite de siyasal kurumlardan dışlanan sosyalist solun siyasal faaliyet gösterebilmesinin bir diğer mekanizması olarak gündeme gelir. Bu açıdan dernek vb şeklindeki örgütler, dergi ve yayın çevreleri içerisinde yürütülen siyasi faaliyetler ve diğer legal partilerin içerisinde yürütülen simbiyotik siyasal oluşumlar bu informal örgütlenme pratiğinin somut tezahürleri olarak ele alınabilirler. 


\section{REFERENCES}

Amnesty International. (1989). Amnesty International Report 1988. London: Amnesty International Publications.

Bennington, G. (1997). Politics of Friendship, a Discussion with Jacques Derrida. Centre for Modern French Thought, The University of Sussex, Access Date: 05.12.2018, http://hydra.humanities.uci.edu/derrida/pol+fr.html

Bora, T. (2016). Türk Sağı: Siyasi Düşünce Tarihi Açısından Bir Çerçeve Denemesi, İ. Ö. Kerestecioğlu ve G. G. Öztan (Der.), Türk Să̆ı, Mitler, Fetişler, Düşman Imgeleri içinde (s. 9-28). İstanbul: İletişim Yayınevi.

Bottomore, T. (1964). Elites and Society. New York: Basic Books Inc.

Burak, B. (2011). Turkish Political Culture and Civil Society: An Unsettling Coupling?. Alternatives Turkish Journal of International Relations, 10(1), 59-71.

Cooper, M. (2002). The Legacy of Ataturk: Turkish Political Structures and Policy-Making. International Affair, 78, 115-128.

Demirkol, M. (2013). From Ottoman to Republic Center-Periphery Analysis in Turkish Political Culture and Bureaucracy. International Anatolia Academic Online Journal, 1(2), 70-85.

Derrida, J. (1974). Of Grammatology. Washington: John Hopkins University Press.

Dizerega, G. (1991). Elites and Democratic Theory: Insights from the Self-Organizing Model, The Review of Politics, 53 (2), 340-372.

Erdal, H. (1983). Discussions in the CPT 1981-1982, Documents. London: Verso.

Family Tree of the Turkish Radical Left. Access Date: 05.12.2018, https://www.broadleft.org/tr_left_part_hist_diag.pdf

Feroze, M. R. (1976). Islam and Secularism in Post-Kemalist Turkey. Islamabad: Islamic Research Institute.

Frey, G. (1965). Turkish Political Elite. Massachusetts: M.I.T. Press. 
Geyikdaği, M. Y. (1984). Political Parties in Turkey, The Role of Islam. New York: Prager Inc.

Hale, W. M., William, M. (1994). Turkish Politics and the Military. London: Routledge.

Harris, G. S. (1967). The Origins of Communism in Turkey. Stanford: Hoover Institution on War, Revolution \& Peace.

Heper, M. (1976). The Recalcitrance of the Turkish Public Bureaucracy to "Bourgeois Politics": A MultiFactor Political Stratification Analysis. Middle East Journal, 30(4), 485-500.

Heper, M. (1985). The State Tradition in Turkey. Wallington, England: The Eothen Press.

Heper, M. (1994). Politics in the Third Turkish Republic. Boulder: Westview Press.

Higley, J., Pakulski, J. (2012). Elite, Elitism and Elite Theory: Unending Confusion?. International Political Science Association, XXII World Congress. Madrid. Access Date: 05.12.2018, http://paperroom.ipsa.org/papers/paper_11235.pdf

Jenkins, G. (2001). Context and Circumstance: The Turkish Military and Politics, Oxford: Oxford University Press.

Karpat, K. H. (1973). Social Change and Politics in Turkey: A Structural-Historical Analysis, Leiden: E. J. Brill.

Kaynar, M. K. (1999). Sosyalizm ve Devrimci Şiddet. I. International Security Symposium, Elazığ, 27-29 March.

Kaynar, M. K. (2007). Türk Solu, Öteki, Milliyetçilik: Türk Solunda Milliyetçiliğin Nedenleri Üzerine Bir Tartışma. Fikret Başkaya (Ed.), Milliyetçilik Yurtseverlik ve Sol içinde (s.77-116). Ankara: Türkiye Ortadoğu Forumu.

Kerestecioğlu, İ.Ö. (2016). Korku ve Siyaset: Türk Sağının Ezberlerini Bozmak, İ. Ö. Kerestecioğlu ve G. G. Öztan (Der.), Türk Sağı, Mitler, Fetişler, Düşman Imgeleri, içinde (s.29-43). İstanbul: İletişim.

Keyder, Ç. (2014). Türkiye'de Devlet ve Sinıflar. İstanbul: İletişim.

Khan, S. R. (2012). The Sociology of Elites. Annual Review of Sociology, 38(1), 361-377.

SAD / JSR

Cilt / Volume 22 Sayı / Number 1 
Lipovsky, I. (1992). Socialist Movement in Turkey: 1960-1980. Leiden: E.J. Brill.

Lopez, M. (2013). Elite Theory. Sociopedia.isa, Acces Date: 02.04.2019, http://www.sagepub.net/isa/resources/pdf/elitetheory.pdf.

Marcus, M. (1982). Overt and Covert Modes of Legitimation in Eastern European Societies. Rigby T.H. and Feher F. (Ed.), Political Legitimation in The Communist States içinde (p. 82-93). New York: St. Martin Press.

Morrison, E. (1999). Politics of Friendship. Variant, 2(7), 55-67.

Mouffe, C. (2000). Carl Schmitt and the Paradox of Democracy. The Democratic Paradox, (p. 36-59). London: Verso.

Özcan, Y. (2015). The European Transformation of Turkish Bureaucratic Elites. Journal of The Academic Elegance, 2(3), 147-189.

Öztan, G. G. (2016). Türk Sağında Devlet Fetişizmine Dair. İ. Ö. Kerestecioğlu ve G. G. Öztan (Der.), Türk Să̆l, Mitler, Fetişler, Düşman İmgeleri içinde (s. 425-458). İstanbul: İletişim Yayınları.

Palma, G. D. (1991). Legitimation from the Top to Civil Society: Political Cultural Change in Eastern Europe. World Politics, 44(1), 49-80.

Pustu, Y. (2007). Osmanl1-Türk Devlet Geleneğinde Modernleştirici Unsur Olarak Bürokratik Elitler. Gazi Üniversitesi İktisadi ve İdari Bilimler Fakültesi Dergisi, 9(2), 197-214.

Sayin, Ç. (2006). What Does the Turkish Bureaucracy Represent? Manifestation of State-Society Relationship in The Meaning Worlds of Bureaucracy, Yayınlanmamıs Doktora Tezi, Ankara: ODTÜ, Sosyal Bilimler Enstitüsü.

Schmitt, C. (1976). The Concept of Political, George Schwab (Trans). New Jersey: Rutgers University Press.

Türkiye İnsan Haklari Vakfi. (1996). 1996 Yılı İnsan Hakları Raporu, Yayın No 18, Ankara: İnsan Hakları Vakfi Yayınları.

Yaş11, F. (2015). Komünizm: İçimizdeki Şeytan. İsmet P. (Der.), Ötekinin Var Olma Sancısı içinde (s. 151214), Bursa: Dora Yayınları. 